\title{
Welding of Niobium to Stainless
}

\author{
M. Kuchnir and Roger E. Hiller \\ Fermi National Accelerator Laboratory \\ P.O. Box 500, Batavia, Illinois 60510
}

March 2, 1993 


\section{Disclaimer}

This report was prepared as an account of work sponsored by an agency of the United States Government. Neither the United States Government nor any agency thereof, nor any of their employees, makes any warranty, express or implied, or assumes any legal liability or responsibility for the accuracy, completeness, or usefulness of any information, apparatus, product, or process disclosed, or represents that its use would not infringe privately owned rights. Reference herein to any specific commercial product, process, or service by trade name, trademark, manufacturer, or otherwise, does not necessarily constitute or imply its endorsement, recommendation, or favoring by the United States Government or any agency thereof. The views and opinions of authors expressed herein do not necessarily state or reflect those of the United States Government or any agency thereof. 


\section{Welding of Niobium to Stainless}

M. Kuchnir and Roger E. Hiller

Fermi National Accelerator Laboratory

P.O. Box 500, Batavia, IL 60510

March 2, 1993 revised November 2, 1993

The present concept of the TESLA accelerator involves superconducting cavities made of pure Niobium cooled by superfluid Helium contained in stainless steel cryostats. The design of these components can be simplified if the welding of pure Niobium to stainless steel can be made in a straightforward manner. There is mention in the literature ${ }^{1}$ that welds of Niobium to structural materials like steel are brittle. We report here our experience with a testing piece containing two such welds. It was made in preparation for the design of a testing facility for side-couplers. Side-couplers are semirigid coaxial elements that conduct the $1.3 \mathrm{GHz} \mathrm{RF}$ power from room temperature to the superconducting cavities at $1.9 \mathrm{~K}$. The weld tests showed at first very encouraging results, but later, when inadvertently submitted to tension the main weld cracked. Nevertheless, we find the material this technical note relevant since such welds when designed into low tension situations have a good chance of performing.

The weld in question joins a Niobium tube passing through a hole in a stainless steel plate to this plate in a superfluid leak-tight seal. The tube has an outside diameter of $76.2 \mathrm{~mm}$ and a $1.59 \mathrm{~mm}$ thick wall. The plate is $4.76 \mathrm{~mm}$ thick and made out of type 304 stainless. Figure 1 is a drawing of the test-piece incorporating one such weld among others and allowing us to check for vacuum leaks at cryogenic temperatures

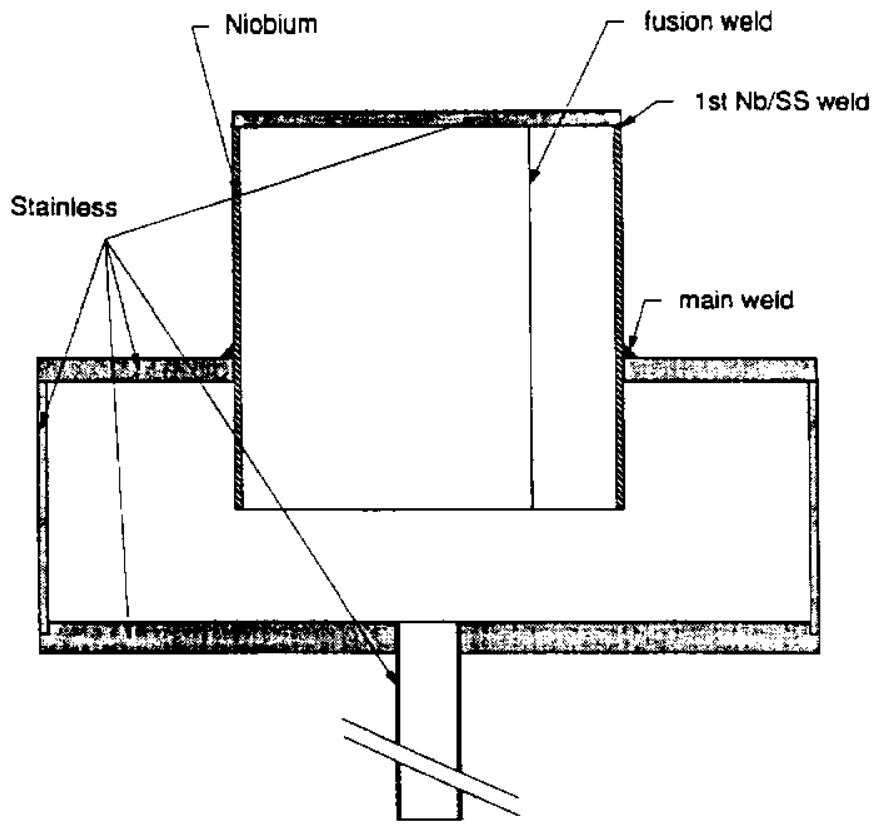

Figure 1. Test-piece for Niobium-Stainless welds

We proceed now to describe the manufacture of this test-piece. The Niobium tube was manufactured by roll forming a well characterized 2 Niobium sheet into a tube, and fusing the edges which were flat (i.e. not completely rolled). The high melting temperature of Niobium $(3114 \mathrm{~K}$ ) and its easy oxidation above $672 \mathrm{~K}$ required this 
operation and all welding involving Niobium to be done in a Helium filled glove box. Upon re-rolling of the tube after fusion-welding to remove the flat spot, this fusion-weld cracked. It was then redone and the flat distortion left on to be compensated by appropriate customizing of the hole in the stainless plate. The next weld, of the Niobium tube to the type 304 stainless disk cap was done using a type 309 stainless filler rod, which had shown some promise in a preliminary tack weld try. Inspection of this weld revealed several transversal cracks. It was then re-welded using a filler rod of Tig-Tectic $680^{3}$. The weld turned out bulky but vacuum tight. The main weld was then done using the latter filling rod, again in the Helium atmosphere of a glove box. It should be pointed out that the melting temperature range of type 304 stainless steel is $1670-1720 \mathrm{~K}$, far below the Niobium melting point but considerably above its oxidation temperature. After the other stainless to stainless welds were made the test-piece was vacuum checked at room temperature $(300 \mathrm{~K})$ and at $78 \mathrm{~K}$.

The low temperature vacuum check was carried out using a Mylar bag around the test-piece, filling it with Helium gas through a Teflon tube and dipping the test-piece so wrapped into liquid Nitrogen, all this while its inner volume was connected to a vacuum purnp through a mass spectrometer type leak detector. This operation was repeated three times with warm ups to room temperature in between. There was no sign of a leak. The sensitivity of the leak detector used is $4.0 \times 10^{-10} \mathrm{~atm} . \mathrm{cm}^{3} / \mathrm{s}$. Since most of the differential contraction between the materials involved between $300 \mathrm{~K}$ and $1.9 \mathrm{~K}$ already takes place by $78 \mathrm{~K}$ this test was considered adequate, and our experience give us confidence that the seals are superfluid leak tight. This confidence is further based on the expansion coefficients 4 involved: stainless contracts $0.296 \%$ while Niobium contracts $0.143 \%$ over the $300-4 \mathrm{~K}$ temperature range and the weld design places the stainless around the Niobium.

One extra care should be taken in welding Niobium for TESLA: Niobium, when heated above $672 \mathrm{~K}$, readily absorbs Oxygen and its purity, essential in these superconducting cavities, will get compromised. So the parts should be left to cool completely in the Helium atmosphere of the glove box. Also, eliminating residual Oxygen in the glove box (by evacuating the glove box prior to admitting Helium) would contribute to satisfy this concern. The welding gas used in these TIG (Tungsten Inert Gas) welds was Argon.

The inadvertent creation of an external vacuum to the test piece during a later leak testing operation placed the main weld in tension and caused it to crack. It should be pointed out that these welds are somewhat magnetic and we have not checked the superconducting and thermal conducting properties of the Niobium tube as processed. project.

We thank Mark Ruschman and Frank E. Juravic for the leak tests involved in this

REFERENCES:

$1_{R}$. Terrence Webster, Metals Handbook 9th Edition,vol. 6, Welding Brazing and Soldering p.459, American Society for Metals (1983)

${ }^{2}$ Produced and characterized by Teledyne Wah Chang Albany, P.O. Box 460, Albany, Oregon 97321, tel. (503)926-4211.

${ }^{3}$ Manufactured by Eutectic Corporation, 40-40 172nd Street, Flushing, NY, 11358-9981, tel. (718)3584000 .

${ }^{4}$ RJ. Corruccini and J.J. Gniewek, "Thermal Expansion of Technical Solids at Low Temperatures",

National Bureau of Standards Monograph 29 (1961). 